\title{
EDITORIAL
}

\section{IN THE DECEMBER 2004 ISSUE OF CLINICS}

\author{
Mauricio Rocha-e-Silva, Editor
}

Our previous issue, published in October introduced our new style. The Editorial Board is in the process of reorganization, to cover a worldwide spectrum of expertise. This December issue of volume 59 of the Revista do Hospital das Clínicas closes a cycle. As from the volume 60 (1), to be published in February 2005, our name changes to CLINICS. We are on course to start with electronic online editoring from the beginning of 2005. If you plan to submit articles to CLINICS after that date, please lookout for our new online submission system in www.scielo.br/clinicas. For some time, however we will still be accepting papers submitted in the orthodox manner. In this final number of 2004 we publish seven papers describing original research, one case report and two reviews.

Sapienza et al. ${ }^{1}$ retrospectively evaluated bone pain palliation and medullar toxicity after samarium-153 therapy in seventy-three patients with metastatic bone pain and conclude that this is a valuable method for such palliation. A mild to moderate and transitory myelosuppression is the main toxic effect observed after the therapy, showing a weak correlation with dosimetric measures.

Mion et al. ${ }^{2}$ evaluated the incidence of hypertension in the São Paulo University general hospital staff, through a stratified sample of 864 out of the total 9,905 employees. Hypertension prevalence was found to be higher than in the general population of the same city; it was lowest in physicians and members of the nursing staff. It is recommended that high-risk groups (obese, non-white, men, low family income) should be better advised on prevention and early diagnosis of hypertension by means of special programs.

Savoia and Bernik ${ }^{3}$ address the interaction between adverse life events and coping skills in panic disorder by comparing 43 panic patients to 29 control subjects regarding the occurrence and the impact of stressful life events in a 1-year period preceding the onset of panic attacks using the appropriate questionnaires. The number of reported stressful life events did not differ between groups, but panic patients reported loss of social support as the most meaningful class of events. In response to stressful situations, panic patients more often used coping skills judged as ineffective in comparison to controls.

Ferrari et al. ${ }^{4}$ evaluated the natural history of iliac artery stenoses in 38 patients with intermittent claudication

From Hospital das Clínicas, Faculty of Medicine, University of São Paulo - São Paulo/SP, Brazil.

E-mail: mrsilva@incor.usp.br undergoing clinical treatment. The lesion was initially diagnosed through arteriography, but follow-up was through magnetic resonance angiography. The progression of a stenosis to occlusion, which occurred in $25 \%$ of the cases, during an average follow-up period of 39 months caused clinical deterioration. Clinical treatment was important, but did not forestall occlusion, which could only be prevented by early endovascular intervention.

Ribeiro et al. ${ }^{5}$ described the effects of a glutamine enriched diet on weight loss and the morphometry of the intestinal mucosa after massive intestinal resection in a rat model. The presence/ absence of glutamine in the diet had no effect on the weight curve, but absence caused decreased intestinal mucosal villi height, crypt depth and thickness. No differences were observed between a standard diet and a glutamine enriched diet. It was concluded that glutamine plays an essential role in maintaining adequate mucosal structure in this condition.

Bernik et al. ${ }^{6}$ endeavored to determine whether bethanecol chloride may be useful for the clinical management of clomipramine-induced orgasmic dysfunction, reported to occur in up to $96 \%$ of male users. Twelve remitted panic disorder patients, with severe clomipramine-induced ejaculatory delay, were randomly assigned to either bethanecol chloride or placebo in a 
randomized, double-blind, placebocontrolled, two-period crossover study. Improvement was observed in the active treatment period. No placebo or carry-over effects were observed. Thus, bethanecol chloride given 45 minutes before sexual intercourse may be useful for clomipramine-induced orgasmic dysfunction in males.
Vieira et al. ${ }^{7}$ evaluated the impact of clinical, pathologic, and surgical variables on the postoperative morbidity, mortality, and survival of 95 patients undergoing extended resections of colon carcinoma from 1953 to 1996. Eighty-six patients were treated by curative surgeries, eight by palliative resections. The 5-year overall survival rate for patients undergoing curative and palliative surgeries was $58.3 \%$ and $0 \%$, respectively. Karnofsky performance status was strongly related to the risk of postoperative complications $(P=$ $.01)$. Palliative-intent procedures may offer benefit, but should be avoided in patients with low Karnofsky performance status due to poor survival.

\section{REFERENCES}

1. Sapienza MT, Ono CR, Guimarães MIC, Watanabe T, Costa PA, Buchpiguel CA. Retrospective evaluation of bone pain palliation after samarium-153-EDTMP therapy. Rev. Hosp. Clín. Fac. Med. S. Paulo 59(6):321-328.

2. Mion Jr. D, Pierin AMG, Bambirra AP, Assunção JH, Monteiro JM, ChineN RY et al. Hypertension in employees of a University General Hospital. Rev. Hosp. Clín. Fac. Med. S. Paulo 2004;6:329-336.

3. Savoia MG, Bernik M. Adverse life events and coping skills in panic disorder. Rev. Hosp. Clín. Fac. Med. S. Paulo 59(6):337340 .

4. Ferrari FB, Wolosker N, Rosoky RA, D'Ippolito G, Wolosker AMB, Puech-Leão P. Natural history of stenosis in the iliac arteries in patients with intermittent claudication undergoing clinical treatment. Rev. Hosp. Clín. Fac. Med. S. Paulo 59(6):341-348.
5. Ribeiro SR, Pinto Jr. PE, Miranda AC de, Bromberg SH, Lopasso FP, Irya K. Weight loss and morphometric study os intestinal mucosa in rats after massive intestinal resection. Influence of a glutamine-enriched diet. Rev. Hosp. Clín. Fac. Med. S. Paulo 59(6):349-356.

6. Bernik M, Vieira AHG, Nunes PV. Bethanecol chloride for treatment of clomipramine-induced oegasmic dysfunction in males. Rev. Hosp. Clín. Fac. Med. S. Paulo 59(6):357-360.

7. Vieira RAC, Lopes A, Almeida PAC, Rossi BM, Nakagawa WT, Ferreira FO et al. Prognostic factors in locally advanced colon cancer treated by extended resection. Rev. Hosp. Clín. Fac. Med. S. Paulo 59(6):361-368. 